\title{
THE
}

2015

\section{Valuation of Expectations: A Hedonic Study of Shale Gas Development and New York's Moratorium}

Andrew Boslett

University of Rhode Island, aboslet1@uri.edu

Todd Guilfoos

University of Rhode Island, guilfoos@uri.edu

Corey Lang

University of Rhode Island, clang@uri.edu

Follow this and additional works at: https://digitalcommons.uri.edu/enre_facpubs

The University of Rhode Island Faculty have made this article openly available.

Please let us know how Open Access to this research benefits you.

This is a pre-publication author manuscript of the final, published article.

Terms of Use

This article is made available under the terms and conditions applicable towards Open Access

Policy Articles, as set forth in our Terms of Use.

\section{Citation/Publisher Attribution}

Boslett, A., Guilfoos, T., \& Lang, C. (2015). Valuation of Expectations: A Hedonic Study of Shale Gas Development and New York's Moratorium. Journal of Environmental Economics and Management, 77(2016), 14-30.

Available at: http://www.dx.doi.org/10.1016/j.jeem.2015.12.003

This Article is brought to you for free and open access by the Environmental and Natural Resource Economics at DigitalCommons@URI. It has been accepted for inclusion in Environmental and Natural Resource Economics Faculty Publications by an authorized administrator of DigitalCommons@URI. For more information, please contact digitalcommons-group@uri.edu. 


\title{
VALUATION OF EXPECTATIONS: A Hedonic Study of Shale Gas Development and New YorK’s Moratorium
}

\author{
Andrew Boslett, Todd Guilfoos and Corey Lang* \\ University of Rhode Island
}

\begin{abstract}
This paper examines the local impacts of shale gas development (SGD). We use a hedonic framework and exploit a discrete change in expectations about SGD caused by the New York State moratorium on hydraulic fracturing. Our research design combines difference-indifferences and border discontinuity, as well as underlying shale geology, on properties in Pennsylvania and New York. Results suggest that New York properties that were most likely to experience both the financial benefits and environmental consequences of SGD dropped in value $23 \%$ as a result of the moratorium, which under certain assumptions indicates a large and positive net valuation of SGD.
\end{abstract}

Keywords: shale gas development; hydraulic fracturing; hedonic valuation; expectations; rational expectations; moratorium; difference-in-differences; border discontinuity

JEL codes: Q3, Q5

\footnotetext{
* Corresponding author. 214 Coastal Institute, 1 Greenhouse Rd., Kingston, RI, 02881. Phone: 401-874-4569. Email: clang@uri.edu.

We thank Branko Boskovic, Michael Delgado, Dennis Guignet, Martin Heitzelmann, Gal Hochman, Neha Khanna, Lucija Muehlenbachs, Tom Sproul, Chris Timmins, Jeremy Weber, Nikolaos Zirogiannis, seminar participants at Cornell University, Fordham University, Rutgers University and University of Minnesota, participants at the 2014 NAREA workshop on non-conventional oil and gas energy and the 2014 NARSC conference, and two anonymous referees for useful suggestions. We are grateful to county planning and real property departments, Nicholas Berry of the NYS Department of Taxation and Finance, Southern Tier Central Regional Planning and Development Board, Debbie Kolodziej, FracTracker Alliance, Natural Gas Forum For Landowners, Elisabeth Radow, David Messersmith, and Attorney Douglas Clark, who have helped us obtain data, understand the timeline of shale gas development, regulation and financial impacts. We acknowledge funding from Rhode Island Agricultural Experiment Station (contribution \#5438). Any errors are our own.
} 


\section{INTRODUCTION}

Shale gas development (SGD) has dramatically changed the US energy landscape in the last decade. The Energy Information Administration (2013) predicts that the US will shift from being a net importer to a net exporter of natural gas by 2020 and domestic production will increase $44 \%$ by 2040. Much of the attention on SGD has been on the Marcellus Shale, which extends over 95,000 square miles across New York, Ohio, Pennsylvania, and West Virginia (Kargbo et al., 2010). Marcellus drilling began in 2005 and has been the source of considerable extraction. From 2005 to 2014, 7,797 unconventional wells have been drilled in Pennsylvania alone.

While the macroeconomic benefits to the US economy are clear, there is uncertainty surrounding the local benefits and costs to households and communities impacted by SGD. Property owners with mineral rights can receive substantial gas lease and production royalties (Pennsylvania Department of Environmental Protection, 2012); however, little is known about the magnitude of payments due to the private nature of the contracts. Potential costs of SGD could include various health and environmental impacts such as water pollution, air pollution, and traffic congestion. The impacts from the health and environmental externalities are also highly uncertain.

Given the current scale of SGD and expected growth in the future, it is critical to understand to the local valuation of SGD. This paper seeks to answer this question using a hedonic framework, as housing prices should reflect the future stream of benefits and costs tied to the property. Empirically, this is hindered in two ways. First, the location of wells may be endogenous. Second, expectations about SGD form in advance of actual drilling, and if expectations are capitalized into housing prices, then a simple before-after comparison may lead to incorrect inference about the valuation. We mitigate these confounding factors by specifically focusing on expectations and using an exogenous shift in expectations to reveal valuation.

Just as hydraulic fracturing was beginning its exponential increase in Pennsylvania, New York State implemented a de facto moratorium on hydraulic fracturing on July 23, 2008, citing uncertainty about health and environmental impacts (State of New York's Executive Chamber, 2008). ${ }^{1}$ The state extended the moratorium multiple times between 2010 and 2014

\footnotetext{
${ }^{1}$ There is considerable heterogeneity in state regulation on shale gas development as a result of different political,
} 
(e.g., Wiessner, 2011) and, on December 17, 2014, the New York Department of Environmental Conservation implemented a permanent ban (Kaplan, 2014). These decisions were highly contentious, as evidenced by several dozen towns in New York passing resolutions in support of SGD in the spring and summer of 2012 and 15 towns are currently considering secession (Mathias, 2015). ${ }^{2}$ To date, there has been no hydraulic fracturing in New York.

This paper exploits changes in expectations that resulted from New York's moratorium on drilling and measures this event's impact on housing prices. Importantly, the moratorium did not mark a change in the amount of hydraulic fracturing in New York - expectations about future SGD are the only thing that changed.

We estimate the effect of the statewide moratorium using a difference-in-differences methodology. We use Pennsylvania as a counterfactual because expectations about future SGD were likely similar to those in pre-moratorium New York, but in contrast with New York, those expectations were realized. Our aim is to identify the change in prices for properties in New York that are most likely to be impacted by SGD (both positively and negatively), relative to price changes for similar properties in Pennsylvania. We use private well water use as a proxy for properties likely to experience SGD. ${ }^{3}$ These are essentially rural properties outside of municipal water supply boundaries, meaning they have the space requirements for drilling. Further, contaminated well water is one of the most common and serious environmental costs.

The design of our preferred sample is motivated by a border discontinuity and underlying shale geology. We begin with property transactions data for two Pennsylvania and three New York counties along the border. In the vein of recent border discontinuity designs (e.g., Grout et al., 2011; Turner et al., 2014) and specifically those that use state borders (Holmes, 1998; Rohlin et al., 2014), we restrict observations to be within five miles of the border in order to minimize unobserved differences in price determinants and best model the counterfactual for New York residents. Even after these restrictions, there are still substantial

\footnotetext{
hydrological, and geological dynamics (Kulander, 2013; Richardson et al., 2013). Some states have used a more lenient approach to regulation. For example, Pennsylvania had no specific regulations concerning hydraulic fracturing until early 2010 (Kulander, 2013). Since then, Governor Tom Corbett’s signed Act 13, prohibiting any local regulation or restrictions on shale gas well production (Begos, 2012). Like New York, New Jersey and Maryland have enacted regulations to restrict or ban hydraulic fracturing.

${ }^{2}$ These resolutions could not supersede state law, but were meant to send a signal to state politicians in Albany and were in contrast to the more common local bans and moratoria implemented elsewhere in the state.

${ }^{3}$ While we cannot predict exactly where SGD would occur in New York, 99.8\% of drilling in our Pennsylvania sample occurred in private well water areas.
} 
shale geology differences across the border. Thus, we further restrict observations to be in a specific band of shale thickness, a geological characteristic that strongly affects the amount of gas or oil in a reservoir (Advanced Resources International, 2013). These restrictions are meant to improve the similarity of expectations about future SGD. Post-moratorium spillovers across the border are a threat to identification. However, we contend that these effects are minimal due to pre-moratorium expectations about spillovers, the rapid pace of drilling stemming from high initial prices, the area comprising a single labor market, and southerly flow of surface water.

Using the 5-mile border and shale geology restrictions, our results suggest that the statewide moratorium decreased New York property values 23.1\% for those properties most likely to experience SGD. Relaxing the sample restrictions leads to smaller estimates in the range of $10-21 \%$, which suggests that effects are heterogeneous across our New York counties and that accounting for shale geology is critical for understanding expectations. We estimate a series of robustness checks that test additional shale geology restrictions, test for spillover effects across the state border, and use municipal water properties as an additional control, and results are consistent with point estimates in the range of an 18-26\% drop in housing values.

We interpret these results as a positive net valuation of SGD by buyers and sellers in New York and Pennsylvania. However, this interpretation relies on two assumptions: the expected probability of SGD in pre-moratorium New York is 1 and the expected probability of postmoratorium SGD is 0 and New York and Pennsylvania property owners and buyers accurately valued the negative and positive aspects of SGD prior to the moratorium. ${ }^{4}$ We estimate several models that bolster our confidence in these assumptions. However, if either of these assumptions are false, we are still recovering the effect of the moratorium on property values, which is driven by expectations over financial benefits and environmental externalities of SGD, and this is an important estimate for areas considering bans on hydraulic fracturing. Further, the estimates serve as a validation that expectations are capitalized into property values.

One of the models we use to test the assumptions needed for an interpretation of net valuation is a more traditional model of the effect of proximity to drilling using only our Pennsylvania observations. The results suggest no price impacts of proximity. While one

\footnotetext{
${ }^{4}$ It is possible that as production and leases are exhausted that home prices would fall over shale areas as the mineral rights become less valuable. As discussed in the Section 2.1, the duration of benefits could exceed 30 years and leases are not likely to be exhausted during our study period.
} 
interpretation is that the impacts of drilling are small, we interpret this to mean that ex ante expectations established in the initial expansion of SGD in Pennsylvania were capitalized into property values and were accurate ex post leading property values not to change. These results corroborate our claim that New York households near the border have accurate expectations about SGD, which in turn supports a rational expectations assumption in hedonic valuation.

There are two major contributions of this paper. First, we provide new evidence of local impacts of SGD. Existing hedonic studies (Gopalakrishnan and Klaiber, 2014; Muehlenbachs et al., 2015) find negative impacts of nearby drilling for well-water dependent properties as large as -22\%. However, Gopalakrishnan and Klaiber (2014) also find that negative effects dissipate to a statistical zero 6-12 months after a permit is issued. Our results lead to very different conclusions. One reason may be that both of these studies either use data exclusively from western Pennsylvania or derive most of their identifying variation from western Pennsylvania. A concern is that split estates, where mineral rights are sold separately from the property, are common in western Pennsylvania due to the area's more extensive history of resource extraction (Kelsey et al., 2012). In contrast, split estates are relatively uncommon in our focus area of eastern Pennsylvania and south-central New York. Thus, our data are more likely to recover net effects of SGD because property owners hold mineral rights and will benefit from royalties and lease payments. ${ }^{5}$ Our interpretation of Gopalakrishnan and Klaiber (2014) and Muehlenbachs et al. (2015) is that their estimates capture the negative externality of SGD near private well water, which is critical to understand, but mostly exclude the financial benefits because of the area of study. Consistent with this interpretation are recent survey findings that indicate a majority of property owners that do not hold the mineral rights to their property are dissatisfied with local drilling, whereas a majority of property owners holding mineral rights are satisfied (Collins and Nkansah, 2013). ${ }^{6}$

While the split estate issue is perhaps the most critical, there are other differences between our study and others that could lead to different estimates of the local impact of SGD.

\footnotetext{
${ }^{5}$ While we have no indication that the prevalence of split estates is becoming more common over time in our study period due to property sellers retaining mineral rights, if they were then our interpretation of net valuation may be confounded by changes in what the sale price accounts for. However, if this were an issue, we would expect it to be more prevalent in Pennsylvania where mineral rights are presently valuable than New York. This would attenuate our estimates because Pennsylvania prices would be that much greater than New York prices if estates were not being split, and thus are our estimates of net valuation could be seen as a lower bound.

${ }^{6}$ A survey by Brasier et al. (2013) found that landowners that hold their property's underlying mineral rights have generally lower risk perceptions of SGD.
} 
We incorporate physical attributes of shale geology into the analysis, which existing valuation studies have not utilized. This appears to be important to creating valid counterfactuals in a difference-in-differences framework. Further, our treatment group has no direct experience with SGD, though they seemingly would learn about it as SGD expanded right across the border. Additionally, we are estimating area-level impacts that capture impacts occurring to whole areas, as opposed to a proximity analysis that captures differential impacts for properties nearby drilling. This focus may average away some of the negative effects of SGD if property owners in NY expect that they would be minimally impacted by negative externalities since the placement of future shale gas wells is unknown.

The second contribution is to add to our understanding of how expectations are capitalized into property values. While many hedonic papers implicitly assume expectations exist and recent structural models have incorporated expectations (e.g., Bishop and Murphy, 2011; Ma, 2013), we offer a particularly clean, reduced-form illustration of how expectations factor into prices. The effect of the New York moratorium is to change expectations, whereas the results of the proximity analysis using only Pennsylvania properties support the idea of rational expectations because no price changes occur once drilling commences. This work also complements hedonic studies that show new information can cause capitalization of disamenities, even when levels of dis-amenities do not change (e.g., Pope, 2008; Guignet, 2013).

\section{BACKGROUND}

The first objective of this section is to catalog various estimates of benefits and costs of SGD, which is critical for putting our estimates of the net valuation of SGD in context. Given the private and dispersed nature of financial benefits, it is a contribution of this paper to compile these estimates. The second objective is to give a timeline of SGD in Pennsylvania and SGD regulation in New York.

\subsection{Financial benefits}

During shale gas extraction, owners of sub-surface mineral rights may sign a mineral lease contract with energy production companies, granting them the right to develop mineral deposits underneath their property (Pennsylvania Department of Environmental Protection, 2012). The two primary monetary benefits associated with shale gas production are lease signing 
bonuses and royalty payments. A lease signing bonus is an initial payment, based on acreage, for signing a gas lease contract (Weidner, 2013). Due to the uncertainty of natural gas production, this is perhaps the most important element of the lease (Hefley et al., 2011). The payment level is based on a number of variables, including geological factors, landowner-stipulated restrictions, nearby drilling results, and the current state of the natural gas market (Weidner, 2013). The average per acre signing bonus is $\$ 2,700$ (Hefley et al., 2011), though this can vary from $\$ 50$ to almost \$6,000 (Humphries, 2008; Green, 2010; Eichler, 2013; Rieley, 2014).

The other major monetary benefit is royalty payments, which are recurring payments on a proportion of natural gas production. The minimum royalty rate, set by law, is $12.5 \%$ of the value of extracted natural gas (Pennsylvania Department of Environmental Protection, 2012). However, the negotiated rate can be much higher, depending on the same factors that determine lease payments (Weidner, 2013). According to a Penn State University Extension associate, Marcellus Shale gas production has generated a cumulative total of $\$ 160$ million in royalties for landowners in Bradford County, Pennsylvania as of late 2012 (Loewenstein, 2012).

The lifetime of a single shale gas well is uncertain due to the short history of unconventional well development. Operators typically assume a minimum life of thirty years, though most of the production occurs in the well’s initial years (Hughes, 2010). Despite high decline rates in well production, these time ranges suggest that royalties and potentially renegotiated leases could occur in the future, depending on the terms in the original lease. Other factors that could extend the horizon of payments are the developments over a well pad. First, the nature of horizontal drilling allows operators to drill multiple horizontal laterals from a single vertical well. Second, although much of a well's production occurs within the first year of drilling, much of the oil or gas in the reservoir is not recovered initially. One technique "refracks” old unconventional wells and can return previous levels of production (e.g., Murtaugh et al., 2015). Third, stacked lateral drilling allows operators to drill multiple horizontal wells on top of each other. By targeting multiple zones in a vertical well, an operator can increase ultimate oil or gas recovery (Bosworth et al., 1998). This technique is most useful in thick regions of a shale play.

SGD infrastructure-related benefits can also serve as economic windfalls for landowners. Surface rights owners can receive monetary payments for allowing pipeline, compressor station, and water impoundment construction on their properties. These are often one-time payments. A 
payment for pipeline easement construction is based on the length of the constructed pipeline and can range from \$5-25 per linear foot (Messersmith, 2010). Due to the nuisance factor associated with compressor stations (e.g., Litovitz et al., 2013), payments for their construction can range from hundreds of thousands to millions of dollars (Clark, 2014). Payments for water impoundment construction can range from $\$ 40,000-70,000$, but could potentially be lower or higher given their intended size and permanency (Clark, 2014).

Lastly, governments have the ability to raise revenue through taxing shale gas development, which in turn would have public finance implications. These public finance measures could then be capitalized in housing prices through improvements to public goods and services in local municipalities, such as schools. Pennsylvania did enact an "impact fee” in 2012 through Act 13, retroactive to 2011 activity, which charged a fee on a per-well, per-year basis. ${ }^{7}$ As SGD expands these impact fees could be a considerable source of income for local government; in 2012 impact fees in Pennsylvania brought in \$202 million (Rabe and Hampton, 2015). The distribution of the fees can go to a variety of sources, such as county and municipal governments, various environmental and non-environmental state government agencies, and the state’s legacy fund (Powelson, 2013).These various estimates of monetary benefits highlight the variation and uncertainty of the how much revenue could be expected from future SGD. For additional details, see online appendix Table A1.

\subsection{Costs}

There are also a number of potential landowner costs of nearby shale gas development, which are primarily driven by environmental impacts. The hydraulic fracturing process is highly water intensive, so much of the focus on the environmental costs of SGD revolve around water quantity and quality impacts. Shale gas development has led to large increases in wastewater management needs (Rahm et al., 2013). In Pennsylvania, regional wastewater generation has increased by 540\% since 2004 (Lutz et al., 2013). In terms of water quality, Jackson et al. (2013) find increased levels of methane contamination in groundwater in heavySGD areas, while Olmstead et al. (2013) find evidence of surface water pollution as a result of SGD waste disposal and management processes. In 2014, the Pennsylvania Department of

\footnotetext{
${ }^{7}$ This source of income for Pennsylvania municipalities appears to be significant, but likely not to our study. Our main results rely on 2006 to 2011 data, we contend that this mechanism would have a minimal effect on housing prices and our estimates.
} 
Environmental Protection released a list of more than 250 instances where SGD operations impacted water quality in the state.

In addition, recent research has shown increased air pollution in areas close to shale gas extraction and processing infrastructure (e.g., Litovitz et al., 2013; Rich et al., 2014). Increased air pollution associated with shale gas development may have significant public health implications (e.g., McKenzie et al., 2012). Although the mechanisms are unclear, Hill (2012) finds significant impacts of shale gas extraction on the birth weight of children born in nearby homes. Additional environmental costs have been identified as concerns such as seismicity (Frohlich, 2012), forest loss and fragmentation (Drohan et al., 2012), and ecosystem services and local biodiversity (Evans and Kiesecker, 2014; Kiviat, 2013). For additional details regarding environmental and social impacts of SGD, please refer to Table A2 in the online appendix.

\subsection{Timing of drilling and regulation}

Figure 1 presents a timeline of SGD and regulatory activity in New York and Pennsylvania. Marcellus shale development commenced in 2005 with the horizontal drilling and hydraulic fracture of a previously-drilled vertical well in Washington County, identified as the “Renz No. 1” well (Carter et al., 2011). Positive results from this and other early wells spurred development. Starting in 2008, around the same time as the New York moratorium, unconventional well development rapidly transpired in Pennsylvania, and as of late 2014 a total of 7,797 wells have been drilled. Figure 2 shows the spatial distribution of the 1,468 unconventional wells drilled from 2006 to 2011 in Bradford and Tioga counties.

In early 2008, the NY DEC received well permits to drill into the Marcellus Shale from multiple companies. These actions were preceded by 1-2 years of activity from industry land men, who would approach landowners about signing oil and gas leases. In May 2008, a group of landowners in Broome County struck a multi-million dollar contract with XTO Energy to lease over 50,000 acres. Landowners in other NY towns close to the Pennsylvania border received significant lease offers as well (Wilber, 2014). Online forums and discussions by property owners and landowner coalitions (e.g., Natural Gas Forum For Landowners) suggest that landowners expected significant drilling. This growing excitement was shared by those in the NY DEC's Division of Mineral Resources, which organized a presentation titled "Marcellus

Shale Gas Well Development in New York State” in May 2008 that positively reviewed the state 
government's current capacity to regulate development and that additional environmental regulations were not needed. Clearly, during the years 2006-2008, residents were forming expectations about the probability of SGD in their area, as well as expectations about associated benefits and costs. All available information suggests that New York residents expected SGD, particularly in the southern part of the state near Pennsylvania.

Although excitement regarding the economic benefits of SGD grew as reports of lease activity became public, there were still significant concerns regarding the environmental, social, and public health aspects of drilling (Wilber, 2014). Citing the fact that the state was relying on a previous environmental impact statement of oil and gas drilling from 1992 that did not address the many unique environmental issues associated with SGD (Lustgarten, 2008), Governor David Paterson passed a measure on July 23, 2008 that effectively blocked SGD for the near future. The primary intent of this measure was to postpone development in order to study the environmental and public health impacts of SGD, as well as New York's capacity to regulate it (State of New York's Executive Chamber, 2008).

In late 2009, the New York City’s Department of Environmental Protection published an assessment of the potential impact of SGD within the city’s water supply area in the Catskills Mountain region. The report highlighted the water contamination risk associated with rapid development within the watershed. In the interest of further study of the environmental impacts of SGD, the NY state legislature or governor passed legislation to extend the moratorium multiple times from 2010 to 2013 (Hoye, 2010; New York Senate, 2010; Wiessner, 2011; New York Senate, 2012; New York State Assembly 2013). During this time period, a potential policy was floated that would allow SGD in southern counties bordering Pennsylvania, but only in towns that explicitly approved it (Hakim, 2012). However, this policy was never enacted.

After six years of legislative and executive order action, the situation culminated in a permanent statewide ban on SGD in December 2014 (Kaplan, 2014), driven largely by lingering public health concerns (NY Department of Health, 2014). As a result of this series of policies, no unconventional natural gas development has occurred in New York, which is reflected in Figure 2.

Despite the statewide nature of the moratorium, New York is a home rule state that grants legislative authority to local governments to enact local legislation that may limit state-level intrusion into local matters (Stinson, 1997). Given this history and the discontent with the 
moratorium, 45 New York towns passed resolutions in support of SGD in the spring and summer of 2012 (FracTracker, 2014). Fourteen of these towns are in our sample counties and are shown in Appendix Figure A3. These resolutions were passed by town councils and were not voted on by residents, but likely reflect residents' sentiments. The resolutions had no impact on the ability for gas companies to operate in New York, but were intended to apply political pressure to state policy makers and signal to industry that these towns are supportive of SGD. One of the major landowner groups driving the passage of the resolutions, the Joint Landowners Coalition of New York, sued Governor Cuomo in order to expedite the state's environmental and public health review of SGD (De Avila, 2014).

On the other side of the debate, 176 New York towns implemented local bans or moratoriums on hydraulic fracturing in the event that the statewide moratorium was lifted (FracTracker, 2014). Most of these townships were located in areas of the state that were unlikely to experience significant SGD from the Marcellus Shale due to geological limitations (e.g., low thickness). In our three NY counties, there were only two towns - Owego (Tioga County) and Wayne (Steuben County) - that passed moratoria on shale gas development, both in 2012.

\section{CONCEPTUAL FRAMEWORK}

In this section we present a hedonic property model that incorporates the phenomena of interest, the valuation of expected shale gas development through the enactment of a moratorium. The hedonic valuation methodology, originally presented by Rosen (1974), posits that the price of a heterogeneous good can be decomposed into implicit prices associated with its individual characteristics. By separating the price of the good into its implicit prices, the technique can help illuminate the value of each characteristic. The standard hedonic model assumes that all negative and positive discounted cash flows will be capitalized into the transaction price if there is full information about those attributes that derive benefits and costs.

We apply the hedonic valuation concept to shale gas development through housing prices. The price function is given as $P_{h}=P_{h}(L, S, N, Q(D), G(D))$ where $L$ is a vector of lot characteristics, $S$ is a vector of structural characteristics, $N$ is a vector of neighborhood characteristics, $Q$ is a vector of environmental characteristics, and $G$ are geological characteristics that allow for possible shale gas development (e.g., land overlying shale with 
retrievable gas). Shale gas development is represented by D. Geological attributes, $G(D)$, derive value from financial amenities such as lease and royalty payments that gas companies pay to homeowners to gain access to the shale. The dis-amenities are represented by the effect on environmental characteristics, $Q(D)$. We assume that development of the shale would also reduce environmental quality. ${ }^{8}$ A homebuyer derives utility from these attributes and a composite good $Y$, and is expressed as $U(Y, L, S, N, Q(D), G(D))$. The homebuyer maximizes utility with respect to a budget constraint and the expected utility gained from these attributes in relation to the composite good $Y$.

Prior to development, the expected flow of benefits and costs coming from shale gas development are uncertain and ambiguous in sign. The expected effect of shale development through lease and royalty payments is positive, $\partial G / \partial D>0$. Geological attributes related to shale are considered a normal good and a positive attribute to the hedonic price function, $\partial P_{h} / \partial G>0$. Thus, if households expect SGD to happen, prices will increase for those properties likely to benefit, all else equal. The expected effect of shale development on environmental quality is negative, $\partial Q / \partial D<0$. Since environmental quality is a normal good, $\partial P_{h} / \partial Q>0$, expectations about SGD will decrease prices, all else equal. The expected implicit value, $P_{D}$, derived from shale gas development is

$$
\begin{array}{r}
E\left[P_{D}\right]=\mathrm{E}\left[\frac{\partial P_{h}}{\partial Q} \frac{\partial Q}{\partial D}+\frac{\partial P_{h}}{\partial G} \frac{\partial G}{\partial D}\right] \\
(\text { predicted sign })+-++
\end{array}
$$

Equation 1 defines the expected value of shale gas development, which contains uncertainty of the magnitude of the negative and positive effects of shale gas development. This uncertainty is derived from the fact that information about financial benefits and risks to environmental amenities is imperfect.

Individuals adjust their expectations of the likelihood of SGD when a moratorium is put in place, and this affects prices. This change in expectations is what we will focus on to identify the net valuation of SGD. Without a moratorium, the probability of shale gas development occurring may be high and bounded at 1 , and individuals expect to receive the full value of the shale gas development; when there is a moratorium, the probability of shale gas development is

\footnotetext{
${ }^{8}$ This also represents other dis-amenities that are not environmental in nature but are costs of shale gas development that are born through damage caused by noise pollution, damaged roads, and increased demands on other public infrastructure. We restrict ourselves to this simplified notation for ease of discussion.
} 
0 , and individuals expect to receive zero value of the shale gas development. The change in the expected value of shale gas development is captured by examining the differences in hedonic price functions with and without a moratorium, ceteris paribus. This is the case in Equation 2, where $M=0$ when there is no moratorium and $M=1$ when there is a moratorium.

$$
\text { Expected } S G D \text { Net Benefits }=\left(P_{h}(.) \mid M=0\right)-\left(P_{h}(.) \mid M=1\right)
$$

The change in expectations reveals the value of shale gas development to the area with a moratorium and provides an event that can uniquely identify this change in expectations. This valuation of expectations implicitly includes the negative and positive local amenities of shale development in Equation 1.

Two assumptions are required to interpret the change in prices as net valuation. First, we assume that the probability of SGD is one without the moratorium and zero with it. As discussed in Section 2.3, given that leasing contracts were being signed and drilling permits were being applied for in New York and given the eventual well density in Pennsylvania near the border with New York (Figure 2), we think that residents believed that drilling would come to New York with certainty, especially those areas near the border with Pennsylvania. It is less clear whether expectations dropped to zero following the moratorium, given that it was initially temporary and then made permanent. If the perceived probabilities of the SGD are strictly within the bounds of one and zero, before and after a moratorium, then our model would underestimate the net value of shale gas development. We detail in Section 6.2 two robustness checks that allow for expectations to change slowly or change in the years after the moratorium and results are similar.

Second, we assume that positive and negative impacts of SGD are accounted for equally through expectations. However, it is possible that expectations of negative externalities are discounted, i.e., $E[\partial Q / \partial D]<\partial Q / \partial D$, even if the probability of SGD is 1 . Several reasons for why this would be exist, such as hyperbolic discounting of longer term environmental and health impacts, discounting of external consequences of neighbors' actions, and uncertainty about well placements. If this assumption does not hold, our estimate may reflect financial benefits more than costs. Still, this estimate reveals valuation of expectations about SGD for a population that has not experienced it, which is policy relevant for other areas considering bans. We detail in Section 6.3 a hedonic model that tests for proximity effects of drilling. The results indicate no price effect, which we interpret as buyers and sellers forming accurate expectations prior to 
drilling, and thus prices do not change once drilling begins.

\section{Methodology}

We develop a model that identifies the impact of the New York statewide moratorium on housing prices, and thus reveals the net valuation of expectations about SGD. We employ a difference-in-differences model, which compares properties in New York before and after the moratorium to similar properties in Pennsylvania. As discussed in more detail in the next section, our preferred sample is comprised of properties within five miles of the state border with similar shale geology and only includes private well properties, which are most likely to experience SGD. This choice is motivated by intuition and prior findings; Gopalakrishnan and Klaiber (2014) and Muehlenbachs et al. (2015) find that private water properties are most price responsive to proximate drilling. We define the treatment group to be New York properties and the treatment is the moratorium.

Equation 3 is our main specification:

$$
\begin{gathered}
\ln \left(p_{i}\right)=\beta_{1} N Y_{i}+\beta_{2} \text { PostMoratorium }_{i}+\beta_{3} N Y_{i} \cdot \text { PostMoratorium }_{i} \\
+X_{i}^{\prime} \delta+\varepsilon_{i}
\end{gathered}
$$

where $p_{i}$ is the sales price of property $i, N Y_{i}$ is a binary variable equal to one if the property is located in New York, PostMoratorium $i$ is a binary variable equal to one if the transaction occurs after the New York State moratorium on SGD, and $X_{i}$ is a set of housing, location, and temporal controls. $X_{i}$ also includes a constant to capture the omitted group of properties located in Pennsylvania that transact before the moratorium. Finally, $\varepsilon_{i}$ is the error.

The interpretation of the model coefficients is as follows. $\beta_{1}$ is the pre-moratorium price difference between properties in New York relative to Pennsylvania. $\beta_{2}$ is the price change from pre-moratorium to post-moratorium for Pennsylvania properties. The key coefficient in Equation 3 is $\beta_{3}$, which is the double difference estimate. This term identifies the effect of the moratorium on New York properties, relative to Pennsylvania properties. As discussed in Section 3, our expectation about the sign and magnitude of this coefficient is ambiguous. It could be positive if New York households are concerned about the environmental dis-amenities of SGD and value the delay or ban of SGD. Alternatively, $\beta_{3}$ could be negative if households anticipated economic gains from SGD and house prices had already capitalized that expectation. Lastly, $\beta_{3}$ could be zero if the moratorium did not change expectations or perceived benefits and costs of SGD are 
small. ${ }^{9}$

While the prior section laid out assumptions required to interpret coefficients as net valuation, there are also assumptions required for the difference-in-differences design to be valid. First, we assume that Pennsylvania serves as a good counterfactual for New York, in terms of house price dynamics. One potential concern is that areas in our study had different reactions to the US housing market collapse, which is correlated with the timing of the moratorium. In the Section 5, we show that our sample of Pennsylvania and New York homes follow a similar price trend pre-moratorium. Also, by focusing on observations close to the border, we hope to mitigate unobservable determinants of price trends. ${ }^{10}$

Our sample choice of five border counties was meant to improve the treatment-control comparison. Our refinement to focus in particular on properties within 5 miles of the border with similar shale thickness furthers the strength of the good counterfactual assumption. However, using bordering counties implicitly assumes that spillover effects are minimal. Spillover effects could be either environmental or economic. Environmental spillovers would occur if water or air pollution from SGD were to travel into New York from Pennsylvania. Evidence from Gopalakrishnan and Klaiber (2014) and Muehlenbachs et al. (2015) suggests that effects of water pollution are localized at about $2 \mathrm{~km}$. SGD in our study area is limited to the Susquehanna River Basin, which flows south. Thus, any surface water contamination is also likely to flow south further into Pennsylvania rather than north into New York. ${ }^{11}$ Economic spillovers are increases in employment and spending across the border that indirectly or directly affect the housing market. Our estimates are unlikely to be affected by any economic spillover because our sample is restricted to a small area of just five miles on either side of the border, and thus can be

\footnotetext{
${ }^{9}$ One might think this type of specification and data could also be used to estimate the area level net value of SGD for Pennsylvania. However, we feel this is untrue precisely because expectations in both Pennsylvania and New York would muddle the comparison. A better comparison would be to compare Pennsylvania to some area with no possibility of SGD, with data prior to 2006 marking the pre-treatment time.

${ }^{10}$ Kuminoff and Pope (2013) find that lower value properties experienced larger boom-bust swings than higher value properties. Given the differences in price levels between the two states (see Table 1 and Figure 4), it is possible that our Pennsylvania sample experience a larger bust. However, if this was the case, our estimates would be upward biased, suggesting the impact of the moratorium to be even more negative for New York prices. To test whether differential boom-bust trends may be impacting our results, we estimate models that include a series of $\$ 100,000$ sale price bin fixed effects interacted with year fixed effects to allow differential boom-bust evolution by price tier. Results are consistent with our main results.

${ }^{11}$ An additional possibility is that property owners in pre-moratorium Pennsylvania formed expectations about environmental spillovers from New York into Pennsylvania in the event of SGD in New York. If true, then the New York moratorium may have increased prices in Pennsylvania. We argue that this effect would have been minimal given the evidence of highly localized environmental impacts of drilling from Gopalakrishnan and Klaiber (2014) and Muehlenbachs et al. (2015).
} 
thought of as a single labor market. ${ }^{12}$ An additional argument that applies to these two types of spillovers is that New York residents and potential buyers would have formed expectations about drilling in Pennsylvania and those expectations would be capitalized into prices prior to the moratorium. Thus, while spillovers may occur, they should be expected and already accounted for in house prices.

Second, we assume that the treatment (moratorium) had no effect on the control (Pennsylvania). The main concern here is whether the moratorium on drilling in New York increased drilling in Pennsylvania. We argue that the pace of development in Pennsylvania (and elsewhere) was so rapid in the 2008-2011 timeframe that the lack of drilling in New York had no effect on prices or scarcity in Pennsylvania. Another way for drilling to be impacted would be if horizontal drills could cross state boundaries and extract New York gas from Pennsylvania, but this is in fact illegal. ${ }^{13}$

Third, we assume that the implementation of the New York statewide moratorium was exogenous to the counties in this study. We believe this is a safe assumption for two reasons. One, it is a statewide moratorium, not just a moratorium for the three sample New York counties, and much of the support for the moratorium came from regions in New York outside of this sample. Two, many of the sample towns were and still are against the moratorium as evidenced by the fact that 14 of 37 towns in our New York sample passed resolutions in support of SGD during the spring and summer of 2012, while only two towns passed a moratorium.

\section{DATA}

This study was conducted with property transaction data from five counties along the New York - Pennsylvania border: Chemung, Steuben, and Tioga counties in New York; Bradford and Tioga counties in Pennsylvania. We specifically chose these five counties because 1) the two Pennsylvania counties constitute one of the major clusters of drilling in that state, 2)

\footnotetext{
${ }^{12}$ We additionally examined cross border migration to see if individuals relocated from New York to Pennsylvania after the moratorium. The results, presented in Figure A1 of the appendix, suggest no changes in migration patterns. ${ }^{13}$ It is highly unlikely that horizontal well drilling across state lines has occurred along the NY-PA border. New York has restrictions on how close one can drill to the state boundary (New York State Regulations - Environmental Conservation Law 553.1; personal correspondence with Thomas Noll, Section Chief of the Bureau of Oil \& Gas Permitting and Management in the NY DEC Division of Mineral Resources). Though Pennsylvania does not have an analogous law outlining state border proximity issues, Pennsylvania Department of Environmental Protection officials note that it is unlikely that any horizontal laterals cross over into New York from Pennsylvania (personal correspondence with David Engle, Operations Manager in the Oil \& Gas Division of the Pennsylvania Department of Environmental Protection).
} 
all five counties are primarily agricultural and rural in character and thus make for good comparison, and 3) they border each other so that unobservable determinants of house prices likely follow similar dynamics.

We obtained transactions and property characteristics data from January 1, 2006 through December 31, 2012 from each county's property assessment office and New York's Office of Real Property Tax Services. Sales prices are adjusted to 2011 levels using the CPI (U.S. Bureau of Labor Statistics, 2014). For each property in our dataset, we have information on the number of bedrooms, number of bathrooms, finished living area, acreage, and age of each property in our dataset. Three of the five counties in our dataset include multiple transactions per property. However, Bradford County (PA) and Steuben County (NY) could only provide us with information for the most recent transaction for each property. ${ }^{14}$

In order to identify each property's water supply, we use data from Pennsylvania's Department of Environmental Protection and New York's Department of Taxation and Finance, Office of Real Property Tax Services. Pennsylvania’s data contains public water supply area boundaries, making sold parcel water supply identification straightforward. However, New York's data on water supply access is in parcel centroid format, which represents every parcel in the state by its center point. Using parcel boundaries provided by county and regional planning departments, we connected sales data to water supply data using Geographic Information Systems (GIS). However, a portion of our sold parcels do not overlay a centroid. In order to identify the water supply for each parcel in our transaction set, we follow Muehlenbachs et al. (2015) and create buffers of 100 meters around all public water supply parcel centroids. Then, we assume that all parcels falling outside of these buffers are dependent on well water. Figure A2 in the Appendix presents all transactions in our five counties by water type. The figure makes clear several points. First, private water supply properties are almost exclusively outside of town boundaries. Second, Pennsylvania has a larger share of private water properties than New York. Further, there are very few public water properties within five miles of the border, especially in Pennsylvania.

In total, our original dataset includes 26,138 property transactions across all five counties from 2006 to 2012. We include only single-family residential and mobile homes with private

\footnotetext{
${ }^{14}$ We examined how this data limitation may affect results by only using the latest sale for all counties and coefficients were very similar to the main results presented in Section 6. The results are available upon request.
} 
water, which leaves us with 8,466 observations. ${ }^{15}$ We drop all observations that sold for less than $\$ 10,000$ or more than $\$ 1,000,000$ in 2011 CPI adjusted dollars. Further, we hypothesize that lot size is a key property characteristic for forming expectations about benefits and costs to SGD. Pennsylvania has larger lot sizes on average, so we drop observations that fall outside of the $5 \%$ and $95 \%$ of the lot size distribution to ensure common support between our Pennsylvania and New York samples. Lastly, we drop eight Pennsylvania transactions that occur prior to the moratorium that are located within two miles of a permitted well. We do this such that all transactions pre-moratorium have expectations about SGD, but no realized impacts.

Our analysis of the moratorium uses sales in the time span 2006-2011. 2006 marks the beginning of exploration and lease signings in Pennsylvania and New York. At this point, both properties in Pennsylvania and New York will begin to capitalize expectations about the benefits and costs to hydraulic fracturing, but have yet to experience it. We use 2011 as a cutoff because local resolutions begin to be passed in early 2012. With these cuts, we are left with a sample of 4,976 transactions.

While choosing counties along the border goes a long way towards removing unobservable differences between New York and Pennsylvania observations, we develop four samples that further restrict observations. First, in the vein of a border discontinuity design, two samples are created that limit observations to be within 15 miles of the border and then within five miles of the border. These samples are intended to further minimize possible bias stemming from unobservable, time-varying processes that differentially affect housing prices across the state boundary. Second, we further restrict the 15- and 5-mile samples to only include properties that have similar shale geology. Figure 3 shows the thickness of shale deposits, which is a key driver of extraction potential. ${ }^{16}$ On average, our Pennsylvania counties have thicker shale deposits than in New York, with thickness increasing towards the southeast. In order to ensure that expectations about SGD are similar on either side of the border, we restrict observation to be in the 100-200 feet range of thickness. Our preferred sample, shown by the dashed region of Figure 3, satisfies both the 5-mile border restriction and shale thickness

\footnotetext{
${ }^{15}$ While mobile homes are often excluded in hedonic analyses such as this, we chose to include them because a substantial proportion is located on lots greater than half an acre. We present robustness checks in Section 6 removing mobile homes and results are similar.

${ }^{16}$ Based on a Marcellus Shale thickness map from the Marcellus Center for Outreach and Research at Pennsylvania State University.
} 
restriction and includes 1,018 observations.

Table 1 presents summary statistics for several variables of interest. The first column gives the means for all private water observations in our five counties. The second and third columns give differences in means for New York versus Pennsylvania for pre-moratorium samples for all counties (Column 2) and the preferred sample of observations within 5 miles of the border and of similar shale thickness (Column 3). The purpose of examining these differences is to determine the comparability of New York and Pennsylvania. Following Imbens and Wooldridge (2009), we divide the difference in means by the combined standard deviation to test for substantial differences and mark differences for which this statistic exceeds 0.25 with an asterisk. Table 1 shows there is strong statistical overlap between the samples, lending credence to the research design. We note that the only significant difference is in shale thickness between the samples which is dramatically reduced by using the restricted sample. There is also convergence of socioeconomic characteristics as we restrict our sample to tracts just along the border in our study counties, as shown in Appendix Table A4.

As discussed in Section 4, the critical assumption for our difference-in-differences design to be valid is Pennsylvania must a good counterfactual for New York. The most common way to support this assumption this is to compare pre-treatment price trends, and now having introduced the data, we can do just that. Figure 4 displays price trends for 2006 through July 2008 for the preferred sample. Price trends are similar between New York and Pennsylvania for private water properties, which further bolsters our confidence that the counterfactual created by the control counties is appropriate. In contrast, the pre-moratorium price trends for public water properties do not coincide, which motivated us to not use these properties in our difference-indifferences design. One reason for the non-parallel trends could be the small number of Pennsylvania public water properties near the border. We could expand the sample in order to include more public water properties (and this does indeed improve the alignment of pretreatment trends), but that would defeat the purpose of the border discontinuity. In addition, we tested whether characteristics of transacted properties were different across states after the moratorium. The results presented in Table A3 of the online appendix show that most characteristics, most importantly lot size, are not statistically different across states. 


\section{RESULTS}

\subsection{The effect of the statewide moratorium}

Table 2 presents the main results of our analysis of the effect New York's statewide moratorium on housing prices (Equation 3). We present the double difference coefficients from five models, each with the same specification, but with progressively more stringent sample criteria. As controls, all models include a variety of property-specific characteristics, year fixed effects and township fixed effects. Column 1 includes all transactions in each of our five sample counties. Column 2 restricts transactions to be within 15 miles of the border, while Column 3 further restricts transactions to be within the 100-200 foot shale thickness band. Column 4 requires transactions to be within five miles of the border, while Column 5 further restricts transactions to be within the $100-200$ foot shale thickness band. Column 5 is our preferred specification as differences in unobservable characteristics will be minimized with the border restriction and expectations about SGD should be very similar due to the common thickness.

The coefficient on $N Y^{*}$ PostMoratorium in Column 1 is -0.101 , which indicates that private well water properties declined in price $10.1 \%$ after the moratorium relative to similar properties in Pennsylvania. Restricting the sample to within 15 miles of the border increases the magnitude of the coefficient to -0.13 , and the coefficient grows again to -0.151 when restricting for shale thickness. For the 5 mile sample, the coefficient is -0.209 , and adding shale thickness the coefficient is -0.231 . The results present a clear pattern that coefficients increase in magnitude as sample restrictions are imposed. This pattern indicates that both the border distance restrictions and the shale thickness restriction are important for minimizing unobservable variation and aligning expectations across the border.

Our estimates imply that taking away the expectation of SGD reduces property values and thus indicates a positive valuation of SGD for areas most likely to experience both the financial benefits and environmental consequences of SGD. Combining our preferred estimate of -0.231 and the average, pre-moratorium, New York house price in our preferred sample (\$110,526 in \$2011), the moratorium reduced house values by $\$ 25,531$ on average relative to

Pennsylvania. In turn, we interpret this number as the net present value of an expected stream of costs and benefits of SGD. If we annualize this present value for a 30-year productive well life with 5\% interest, this result translates into an annual net benefit of $\$ 1,649$. One assumption underlying this interpretation is that the probability goes from 1 to 0 with the moratorium. 
Instead, if subjective probabilities were within the bounds of 1 and 0 , then the net value would be larger and equal to $\$ 25,531$ divided by the change in probability. For example, if the probability of SGD changed from 0.9 to 0.4 , then the estimated net present value of SGD would be $\$ 25,531 /(0.9-0.4)=\$ 51,062 .{ }^{17}$ The second assumption necessary for our interpretation is that households have accurate expectations about the benefits and costs that will result from SGD. For instance, if households are accurate in their assessment of financial benefits, but discount the possibility of adverse health or environmental consequences, then our estimate may reflect lost benefits more than the net value. However, in Sections 6.2 and 6.3, we present results that bolster our confidence in these two assumptions.

\subsection{Robustness checks and extensions}

Table 3 provides a series of robustness checks that probe several key assumptions of our difference-in-differences model and our interpretation of the results as revealing net value of SGD. ${ }^{18}$ Each column builds on our main result of Column 5 Table 2, and thus uses both the 5 mile border and shale thickness restrictions. Columns 1 and 2 address the assumption of expectations changing from 1 to 0 with the moratorium. Column 1 excludes transactions occurring in 2008. As there may have been a gradual slide from certainty of SGD to uncertainty to certainty of no SGD, removing the time period which this slide was likely to occur ensures a large discrete and complete change in expectations. The estimated coefficient is -0.244 , which is nearly identical to the main result. Column 2 includes transactions from 2012, which were originally excluded because of the local resolution activity that occurred in New York in the spring and summer of 2012. The coefficient again stays consistent at -0.255 , which suggests that expectations changed with the moratorium and did not change much after that with the multiple

\footnotetext{
${ }^{17}$ Another way in which expectations can affect the calculation of net values is if households have a perceived duration of the moratorium. For example, many people (authors included) had the impression that the initial moratorium would last five years, and then the New York State government would make a decision. In this case, the house price reduction is not the lost value of SGD, but the cost of waiting five years for SGD. At a 5\% interest rate, the annualized value of SGD would be \$7,618. Given results in Section 6.2 that households do not seem to be updating their beliefs, we think the assumption that people believed the moratorium to be temporary is inconsistent with the data. However, future work could examine more recent data to determine if the permanent ban in 2014 led to any price change.

${ }^{18}$ In the appendix, we present additional robustness checks. Table A5 shows the set of control variables. Table A7 estimates models similar to Table 2, but using the level of prices and results are similar. Table A8 tests for robustness of only including single family homes and using propensity score matching to trim the sample for covariate balance, and results are similar. Table A9 tests supports the robustness of our 15 mile border and shale thickness model estimate using models similar to those used in Table 3.
} 
extensions.

Columns 3 and 4 return to the 2006-2011 timespan and test whether alternative shale geology characteristics may better match expectations across the border. Column 3 restricts the data set to only include those transactions that overlay shale that is 150 to 200 feet thick. The resulting parameter estimate -0.260 is similar to our Table 2 estimate. Column 4 additionally requires transactions to overlay shale with similar depth. ${ }^{19}$ Low depth areas of the shale have relatively lower reservoir pressure and higher water content, which may reduce potential oil and gas recovery. However, high depth areas of the shale may be less permeable and have higher drilling costs than low depth areas (Advanced Resources International, 2013). Though ambiguous, it could have an impact on expectations. The estimate from Column 4 is -0.240 , very similar to our estimate without this additional requirement.

Our research design also assumes that environmental spillovers across the border are minimal. In Column 5, we remove observations within 1 mile of the border in hope that any expected or actual spillover is contained to that distance. The estimated coefficient is -0.231 , identical to the main result. $^{20}$

Our final robustness check, Column 6 in Table 3, further probes how well Pennsylvania serves as a counterfactual in terms of house price trends. Here, we use a triple difference specification and include properties that are served by municipal water supply. These properties are in towns and are unlikely to receive either the financial benefits or the main environmental damages associated with water contamination. Their purpose is to serve as an additional control for differential market trends in New York and Pennsylvania. However, our border discontinuity with a five mile distance requirement is designed to mitigate these types of unobservable variables. In addition, the pre-treatment trends did not run parallel (Figure 4), and there are very few public water properties on the Pennsylvania side (Appendix Figure A4). Thus, we do not believe this is the best research design, but investigate it as a robustness check. The triple difference term $N Y *$ PostMoratorium*Private, which is now the coefficient of interest, is interpreted as the change in price due to the moratorium for New York private water supply properties, relative to Pennsylvania private water properties, and relative to the differential

\footnotetext{
${ }^{19}$ Depth is measured based on a Marcellus Shale depth map from the Marcellus Center for Outreach and Research at Pennsylvania State University.

${ }^{20}$ If instead of a 1 mile exposure buffer of environmental effects, there is a 5 or more mile exposure buffer, all New York properties in our preferred sample would be exposed. Under this (extreme) assumption, our estimates would recover the option value of mineral rights.
} 
change between public water properties in New York and Pennsylvania. The coefficient estimate is -0.179 , which is smaller than the main result and less statistically significant. While this result is broadly consistent with the main result, the reduced magnitude is consistent with a premoratorium downward trajectory of municipal water properties in New York relative to Pennsylvania. In sum, the range of estimates from Table 3 support our assumptions and suggest that the moratorium reduced property values between 18\% and 26\% for New York properties overlaying high-quality shale deposits.

In Table 4, we extend our analysis of the effect of the statewide moratorium by examining whether there were heterogeneous price impacts based on lot size and future resolution status of a property's township. ${ }^{21}$ Instead of using our preferred 5 mile distance band in this analysis, we apply a border distance band of 15 miles in order to include more towns that ultimately passed resolutions in 2012. Larger lots may be able to capture more financial benefits through leases and royalties. Owners and potential buyers may expect these financial benefits and so the price decline post-moratorium will be amplified for larger properties. The first column in Table 4 presents results from a specification that builds on our double difference framework by interacting lot size (log acres) with each of the three double difference variables. Resulting parameter estimates indicate that the double difference coefficient of interest is similar in magnitude to the results from Table 2, Column 3. The interaction with lot size is negative (as expected), but is statistically indistinguishable from zero. ${ }^{22}$ We interpret these results as indicating that there is no heterogeneity across lot sizes, which we may be due to the high degree of uncertainty in financial benefits.

The second column of Table 4 explores whether the future resolution status of a town affects price impacts. As noted above, the statewide moratorium was unpopular in certain parts of New York. Towns that eventually pass resolutions likely supported SGD in the 2006-2008 range. Residents and homebuyers may have had larger expectations about the financial benefits, and thus may have a larger price decrease post-moratorium. We estimate a specification that is similar to the preferred specification, but additionally interacts ResolutionTown (= 1 if a property is located in a town that passes a resolution in 2012) with the double difference variable

\footnotetext{
${ }^{21}$ We also estimate a model with only properties smaller than 10 acres to control for properties that have substantial differences in values due to quality and size of the land (due to being used for agriculture). We find our results do not qualitatively change with this restriction.

${ }^{22}$ We also estimated models with different assumptions about the functional form for lot size and results were similar.
} 
$N Y *$ PostMoratorium. The results indicate that residential property prices declined $-12.8 \%$ postmoratorium, similar to the estimate found in Table 2, Column 3. However, we find that this effect does not change in resolution towns. Although the parameter estimate on the triple difference term is negative (-9.8\%), it is not statistically significant. This result suggests that the underlying likelihood of SGD as viewed by homeowners and prospective buyers is no different in resolution towns versus other towns. However, this modeling approach is focused on selection and underlying characteristics, not the effect of the resolution itself. In the appendix, we present an analysis of the property value impacts of passing a resolution. Our results suggest no effect.

\subsection{Proximity analysis}

In this section we develop a more traditional model that estimates the effect of proximity to drilling on house prices. Similar to Gopalakrishnan and Klaiber (2014), we estimate variations on the following model:

$$
\ln \left(p_{i}\right)=\beta_{1} \text { Wells }_{i}+\beta_{2} \text { Wells }_{i} \cdot \text { Private }_{i}+X_{i}^{\prime} \delta+\varepsilon_{i}
$$

where $W_{e l l} s_{i}$ is the number of wells within a given distance of a property, Private $i$ is a binary variable equal to one if the property depends on well water, and $X_{i}$ is a set of housing, location, and temporal controls. Gopalakrishnan and Klaiber (2014) estimate several specifications varying distance cutoffs and time windows, and we follow suit. We implement both a one mile and two mile cutoff for the measure of proximity, and estimate the impact of new wells six and 12 months prior to transaction, as well as any time prior to transaction. We interact the binary variable Private $_{i}$ with $W e l l s_{i}$ to allow for heterogeneous effects of proximity over private versus public water. We use all observations in our threes counties of Pennsylvania from 2006 to 2012. Identification comes from comparing houses within a given distance band of a drilled shale well to houses further away and houses that predated the drilling.

While this model has a traditional interpretation of valuation of proximity, this model also estimates the accuracy of households’ pre-drilling expectations. Because all transactions in this analysis occurred after households began signing leases with gas companies, we claim that expectations of SGD net benefits had already been capitalized into sales prices. Under this interpretation, a post-drilling change in house prices would suggest that expectations were incorrect. Specifically, if prices decline post-drilling, as is the case in prior studies, this would indicate that households’ expectations had either overvalued the financial benefits or 
undervalued the environmental costs.

The results presented in Table 5 suggest that proximity to wells has no effect on house prices. Across all six specifications, neither the public nor private well water coefficients are statistically different from zero. These results are qualitatively robust to changes in functional form. We interpret this to mean that ex ante expectations established in the initial expansion of SGD in Pennsylvania were on average accurate ex post. In turn, these results support our claim that New York households near the border have accurate expectations about SGD. However, an alternative interpretation is there is no economically significant benefit or cost of living in proximity to drilling.

\section{ConClusion}

This paper proposes to view hedonic analysis through a different lens by focusing on the formation, realization, and change of expectations to inform environmental policy. We provide area-level impacts of the statewide moratorium on SGD for households living in New York. Under assumptions of rational expectations of benefits and costs of SGD and the statewide moratorium causing a 100\% change in expectations about the probability of SGD, the results are interpreted as the net valuation of the local impacts of SGD. If expectations did not change $100 \%$, then the estimates could be seen as a lower bound of SGD value. With loss of the rational expectations assumption, we are still recovering the effect of the moratorium on property values, which is driven by expectations over financial benefits and environmental externalities of SGD, and this is an important estimate for areas considering bans on hydraulic fracturing. Our preferred model suggests that the moratorium causes a 23.1\% price decline for New York properties most likely to experience SGD, which indicates a positive and substantial valuation of SGD. Our results measuring proximity effects of drilling in Pennsylvania suggest no price movement after drilling begins. This finding supports the rational expectations assumption, in that expectations of SGD are formed prior to drilling and ex post expectations were accurate in regard to the costs and benefits of SGD.

For our preferred border discontinuity sample, our point estimate translates into a $\$ 25,531$ loss in equity per house and an annualized loss of $\$ 1,649$ per house. In order to estimate the total property market impact to these three counties, we performed the following back-of-the-envelope calculation. The average sales price 2006-2008 for a private water 
property in our three study counties in New York was \$117,283 (in \$2011). Using our -10.1\% estimate derived using all properties, the average house lost $\$ 11,846$ in value due to the moratorium. From the 2000 Decennial Census, these three counties have a total of 99,402 housing units. Based on our transactions data, 30\% (or 29,848) of these are likely to have private water supply. Putting these together, we estimate the total net loss in value for these three New York counties from the moratorium was \$354 million. 


\section{REFERENCES}

Advanced Resources International. 2013. "EIA/ARI World Shale Gas and Shale Oil Resource Assessment.” Report. Prepared for the U.S. Energy Information Administration, U.S. Department of Energy.

Begos, Kevin. 2012. "Pennsylvania Zoning Laws for Gas Drilling, Known as Act 13, Debated in State Supreme Court.” Huffington Post, October 18, 2012.

http://www.huffingtonpost.com/2012/10/18/pennsylvania-gas-drilling-laws_n_1979334.html

Bishop, Kelly C., and Alvin D. Murphy. 2011. "Estimating the Willingness to Pay to Avoid Violent Crime: A Dynamic Approach.” American Economic Review, 101 (3): 625-629.

Bosworth, Steve, Hussein Saad El-Sayed, Gamal Ismail, Herve Ohmer, Mark Stracké, Chris West, and Albertus Retnanto. 1998. "Key Issues in Multilateral Technology.” Oilfield Review, Winter 1998: 14-28.

Brasier, Kathryn J., Diane K. McLaughlin, Danielle Rhubart, Richard C. Stedman, Matthew R. Filteau, and Jeffrey Jacquet. 2013. "Risk Perceptions of Natural Gas Development in the Marcellus Shale.” Environmental Practice, 15: 108-122.

Carter, Kristin M., John A. Harper, Katherine W. Schmid, and Jaime Kostelnik. 2011. "Unconventional Natural Gas Resources in Pennsylvania: The Backstory of the Model Marcellus Shale play.” Environmental Geosciences, 18 (4): 217-257.

Clark, Douglas. 2014. Personal communication.

Collins, Alan and Kofi Nkansah, 2013. “Divided Rights, Expanded Conflict: The Impact of Split Estates in Natural Gas Production.” 2013 Annual Agricultural and Applied Economics Association Meeting. Washington, DC. No. 150128.

Cornell University Cooperative Extension. 2015. “Frequently Asked Questions.” Cornell University Natural Gas Research Center.

De Avila, Joseph. 2014. “Pro-Fracking Group Sues New York Gov. Cuomo.” The Wall Street Journal, February 14, 2014. http://www.wsj.com/articles/SB10001424052702304315004579383251980462952

Drohan, Patrick J., James C. Finley, Paul Roth, Thomas M. Schuler, Susan L. Stout, Margaret C. Brittingham, and Nels C. Johnson. 2012. "Oil and Gas Impacts on Forest Ecosystems: Findings Gleaned from the 2012 Goddard Forum at Penn State University.” Environmental Practice, 14 (4): 394-399. 
Eichler, Alexander. 2013. "Pennsylvania Fracking: A History of Shale Gas Drilling, as Told by the People Who Live There.” The Huffington Post, January 25, 2013. http://www.huggintonpost.com/2013/01/25/pennsylvania-fracking_n_2440227.html

Energy Information Administration, 2013. “Annual Energy Outlook 2013.” Report. U.S. Department of Energy.

Evans, Jeffrey S., and Joseph M. Kiesecker. 2014. "Shale Gas, Wind and Water: Assessing the Potential Cumulative Impacts of Energy Development on Ecosystem Services within the Marcellus play.” PLoS ONE, 9 (2): e89210.

FracTracker. 2014. High Volume Hydrofracking Bans, Moratoria, and Movements for Prohibitions in New York State. October 9, 2014. http://www.fractracker.org/map/us/newyork/moratoria/

Frohlich, Cliff. 2012. "Two-Year Survey Comparing Earthquake Activity and Injection-Well Locations in the Barnett Shale, Texas." Proceedings of the National Academy of Sciences, 109 (35): 13934-13938.

Gopalakrishnan, Sathya, and H. Allen Klaiber. 2013. "Is the Shale Energy Boom a Bust for Nearby Residents? Evidence from Housing Values in Pennsylvania.” American Journal of Agricultural Economics, 96 (1): 43-66.

Green, Elwin. 2010. "Marcellus Shale Could Be a Boon or Bane for Landowners.” Pittsburgh Post-Gazette, February 28, 2010. http://www.postgazette.com/business/businessnews/2010/02/28/Marcellus-shale-could-be-a-boon-or-banefor-land-owners/stories/201002280253

Grout, Cyrus A., William K. Jaeger, and Andrew J. Plantinga. 2011. "Land-Use Regulations and Property Values in Portland, Oregon: A Regression Discontinuity Design Approach.” Regional Science and Urban Economics, 41 (2): 98-107.

Guignet, Dennis. 2013. "What Do Property Values Really Tell Us? A Hedonic Study of Underground Storage Tanks.” Land Economics, 89 (2): 211-26.

Hakim, Danny. 2012. “Cuomo Proposal Would Restrict Gas Drilling to a Struggling Area.” The New York Times, June 13, 2012. http://www.nytimes.com/2012/06/14/nyregion/hydrofracking-under-cuomo-plan-would-berestricted-to-a-few-counties.html 
Hefley, W. E., et al. 2011. "The Economic Impact of the Value Chain of a Marcellus Shale Well.” Working Paper, Katz Graduate School of Business. University of Pittsburgh. Pittsburgh, PA.

Hill, Elaine. 2012. "Unconventional Natural Gas Development and Infant Health: Evidence from Pennsylvania.” Cornell University working paper.

Holmes, Thomas J. (1998), "The Effect of State Policies on the Location of Manufacturing: Evidence from State Borders," Journal of Political Economy, 106 (4), 667-705.

Hoye, Sarah, 2010. “New York Governor Pauses 'Fracking'.” CNN, December 13, 2010. http://www.cnn.com/2010/US/12/13/new.york.fracking.moratorium/

Hughes, J. David. 2010. “Drilling Deeper: A Reality Check on U.S. Government Forecasts for a Lasting Tight Oil \& Shale Gas Boom.” Post-Carbon Institute Paper.

Humphries, Marc. 2008. Memorandum to House Committee on Natural Resources. Attention: 2008. Congressional Research Service.

Imbens, Guido W., and Jeffrey M. Wooldridge. 2009. "Recent Developments in the Econometrics of Program Evaluation.” Journal of Economic Literature, 47 (1): 5-86.

Jackson, Robert B., Avner Vengosh, Thomas H. Darrah, Nathaniel R. Warner, Adrian Down, Robert J. Poreda, Stephen G. Osborn, Kaiguang Zhao, and Jonathan D. Karr. 2013. "Increased Stray Gas Abundance in a Subset of Drinking Water Wells near Marcellus Shale Gas Extraction.” Proceedings of the National Academy of Sciences, 110(28): 1125011255.

Kaplan, Thomas. 2014. “Citing Health Risks, Cuomo Bans Fracking in New York State.” New York Times, December 18, 2014. http://www.nytimes.com/2014/12/18/nyregion/cuomo-toban-fracking-in-new-york-state-citing-health-risks.html

Kargbo, David M., Ron G. Wilhelm, and David J. Campbell. 2010. "Natural Gas Plays in the Marcellus Shale: Challenges and Potential Opportunities.” Environmental Science \& Technology, 44: 5679-5684.

Kelsey, Timothy W., Alex Metcalf, and Rodrigo Salcedo. 2012. "Marcellus Shale: Land Ownership, Local Voice, and the Distribution of Lease and Royalty Payments.” Report. Center of Economic \& Community Development (CECD). Pennsylvania State University. 
Kiviat, Erik. 2013. "Risks to Biodiversity from Hydraulic Fracturing for Natural Gas in the Marcellus and Utica shales.” Annals of the New York Academy of Sciences, 1286: 1-14.

Kulander, Christopher. 2013. "Shale Oil and Gas State Regulatory Issues and Trends." Case Western Reserve Law Review, 63 (4): 1101.

Kuminoff, Nicolai V., and Jaren C. Pope. "The Value of Residential Land and Structures during the Great Housing Boom and Bust.” Land Economics 89, no. 1 (February 1, 2013): 1-29.

Leahy, Andy. 2011. “So When Did New York State’s Moratorium Actually Begin?” NY Shale Gas Now Blog, November 13, 2010. http://nyshalegasnow.blogspot.com/2011/11/so-whendid-new-york-states-marcellus.html

Litovitz, Avisa, Aimee Curtright, Shmuel Abramzon, Nicholas Burger, and Constantine Samaras. 2013. "Estimation of Regional Air-Quality Damages from Marcellus Shale Natural Gas Extraction in Pennsylvania.” Environmental Research Letters, 8 (1): 1-8.

Loewenstein, James. 2012. "Natural Gas Royalties in Bradford County Reach \$160 Million.” The Daily Review, September 25, 2012. http://thedailyreview.com/news/natural-gasroyalties-in-bradford-county-reach-160-million-1.1378260

Lustgarten, Abrahm. 2008. "Governor Signs Drilling Bill but Orders Environmental Update.” ProPublica, July 23, 2008. http://www.propublica.org/article/governor-signs-drilling-billbut-orders-environmental-update-723

Lutz, Brian D., Aurana N. Lewis, and Martin W. Doyle. 2013. "Generation, Transport, and Disposal of Wastewater Associated with Marcellus Shale Gas Development.” Water Resources Research, 49: 1-10.

Ma, Lala. 2013. "Learning in a Hedonic Framework: Valuing Brownfield Remediation.” Working Paper. Duke University.

Mathias, Christopher. 2015. "New York Towns Threaten Secession Over Gov. Cuomo’s Ban On Fracking.” The Huffington Post, February 20, 2015. http://www.huffingtonpost.com/2015/02/20/new-york-fracking-secession-southern-tiercuomo_n_6722296.html

McKenzie, Lisa M., Roxana Z. Witter, Lee S. Newman, and John L. Adgate. 2012. “Human Health Risk Assessment of Air Emissions from Development of Unconventional Natural Gas Resources.” Science of The Total Environment, 424: 79-87. 
Messersmith, Dave. 2010. "Natural Gas Pipeline Right-Of-Ways: Understanding Landowner Rights and Options.” Report. Penn State Cooperative Extension.

Muehlenbachs, Lucija, Elisheba Spiller, and Christopher Timmins. 2015. "The Housing Market Impacts of Shale Gas Development.” American Economic Review, 105(12): 3633-59.

Murtaugh, Dan., Lynn Doan, and Bradley Olson. 2015. "Refracking Is the New Fracking." Bloomberg Business, June 6, 2015. Accessed from: http://www.bloomberg.com/news/articles/2015-07-06/refracking-fever-sweeps-across-shaleindustry-after-oil-collapse

Natural Gas Forum For Landowners. 2014. New York Leasing Forums: http://www.naturalgasforums.com/smf/index.php/board,20.0.html

Olmstead, Sheila M., Lucija A. Muehlenbachs, Jhih-Shyang Shih, Ziyan Chu, and Alan J. Krupnick. 2013. "Shale Gas Development Impacts on Surface Water Quality in Pennsylvania.” Proceedings of the National Academy of Sciences, 110(13): 4962-4967.

Pennsylvania Department of Environmental Protection. 2012. "Landowners and Oil and Gas Leases in Pennsylvania.” 8000-FS-DEP2834.

Pennsylvania Department of Environmental Protection. 2014. Water Supply Determination Letters.

Pope, Jaren. 2008. "Buyer Information and the hedonic: The Impact of a Seller Disclosure on the Implicit Price for Airport Noise.” Journal of Urban Economics, 63 (2): 498-516.

Powelson, Robert F. 2013. "Annual Report of the Collection and Distribution of Funds under Act 13 of 2012.” Pennsylvania Public Utility Commission Report.

Rabe, Barry G., and Rachel Hampton. "Taxing Fracking: The Politics of State Severance Taxes in the Shale Era.” University of Michigan. Center for Local, State, and Urban Policy Working Paper Series 34

Rahm, Brian G., Josephine T. Bates, Lara R. Pertoia, Amy E. Galford, David A. Yoxtheimer, and Susan J. Riha. 2013. "Wastewater Management and Marcellus Shale Gas Development: Trends, Drivers, and Planning Implications.” Journal of Environmental Management, 120: 105-113.

Rich, Alisa, James P. Grover, and Melanie L. Sattler. 2014. “An Exploratory Study of Air 
Emissions Associated with Shale Gas Development and Production in the Barnett Shale.” Journal of the Air \& Waste Management Association, 64 (1): 61-72.

Richardson, Nathan, Madeline Gottlieb, Alan Krupnick, and Hannah Wiseman. 2013. "The State of State Shale Gas Regulation.” Report. Resources for the Future.

Rohlin, Shawn, Stuart S. Rosenthal, and Amanda Ross. "Tax Avoidance and Business Location in a State Border Model.” Journal of Urban Economics 83 (September 2014): 34-49.

Rosen, Sherwin. 1974. "Hedonic Prices and Implicit Markets: Product Differentiation in Pure Competition.” Journal of Political Economy, 82 (1): 34-55.

State of New York's Executive Chamber. 2008. "Governor Patterson Signs Bill Updating Oil and Gas Drilling Law; Pledges Environmental and Public Health Safeguards.” Retrieved from: http://www.governor.ny.gov/archive/paterson/press/press_0723084.html

Stinson, Joe. 1997. "The Home Rule Authority of New York Municipalities in the Land Use Context.” Report. Pace University Law School.

Turner, Matthew A., Andrew Haughwout, and Wilbert van der Klaauw. 2014. "Land Use Regulation and Welfare.” Econometrica, 82 (4); 1341-1403.

Weidner, Krista. 2013. “A Landowner’s Guide to Leasing Land in Pennsylvania.” Pennsylvania State University Cooperative Extension.

Wiessner, Dan. 2011. “NY Assembly Extends Fracking Ban for another Year.” Reuters, June 6, 2011. http://www.reuters.com/article/2011/06/06/us-newyork-frackingidUSTRE7556RR20110606

Wilber, Tom. 2014. "How Fracking Got Stopped in New York." Originally published in the Binghamton Press \& Sun Bulletin, December 22, 2014. http://tomwilber.blogspot.com/2014/12/how-fracking-got-stopped-in-new-york.html 


\section{Tables and Figures}

Figure 1: Timeline of New York policies on shale gas development and the number of wells drilled in Pennsylvania from 2006 to 2014

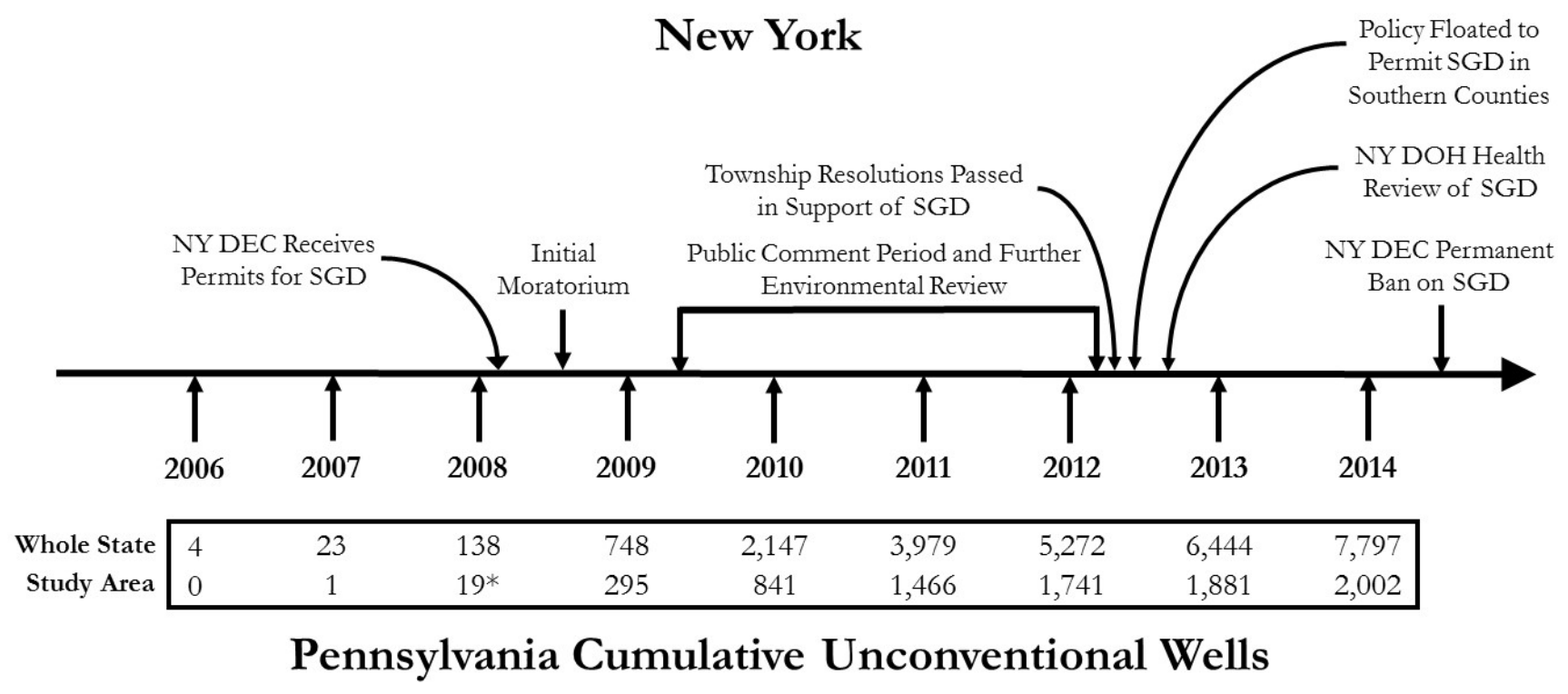

Notes: NY DEC and DOH refer to the Department of Environmental Conservation and Department of Health, respectively. * 5 Wells were drilled in our PA study area in 2008 before the moratorium was implemented in NY on July $23^{\text {rd }}, 2008$ 
Figure 2: Unconventional well development in Bradford and Tioga counties from 2006 to 2011

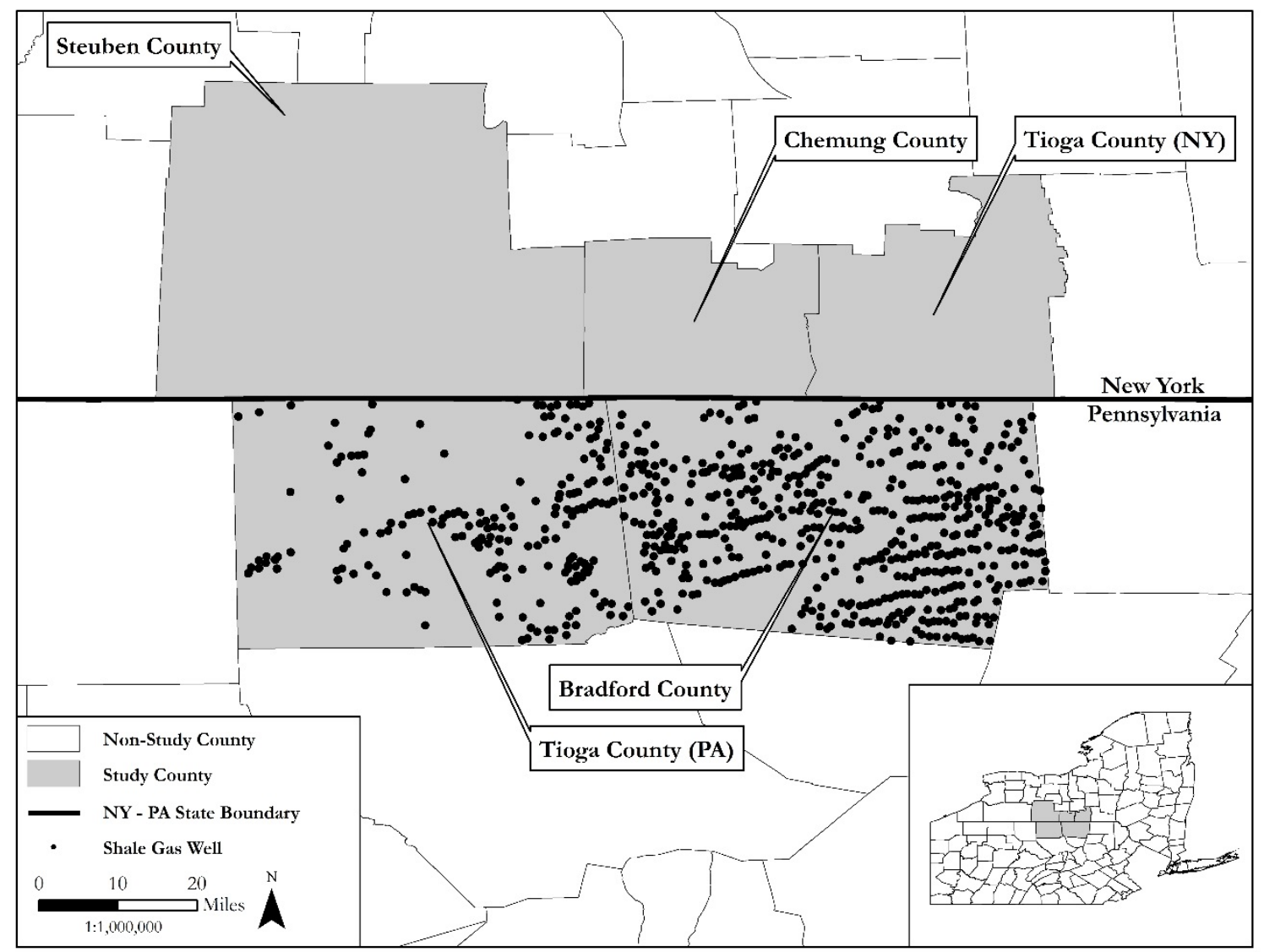


Figure 3: Shale thickness and border restrictions across sample counties

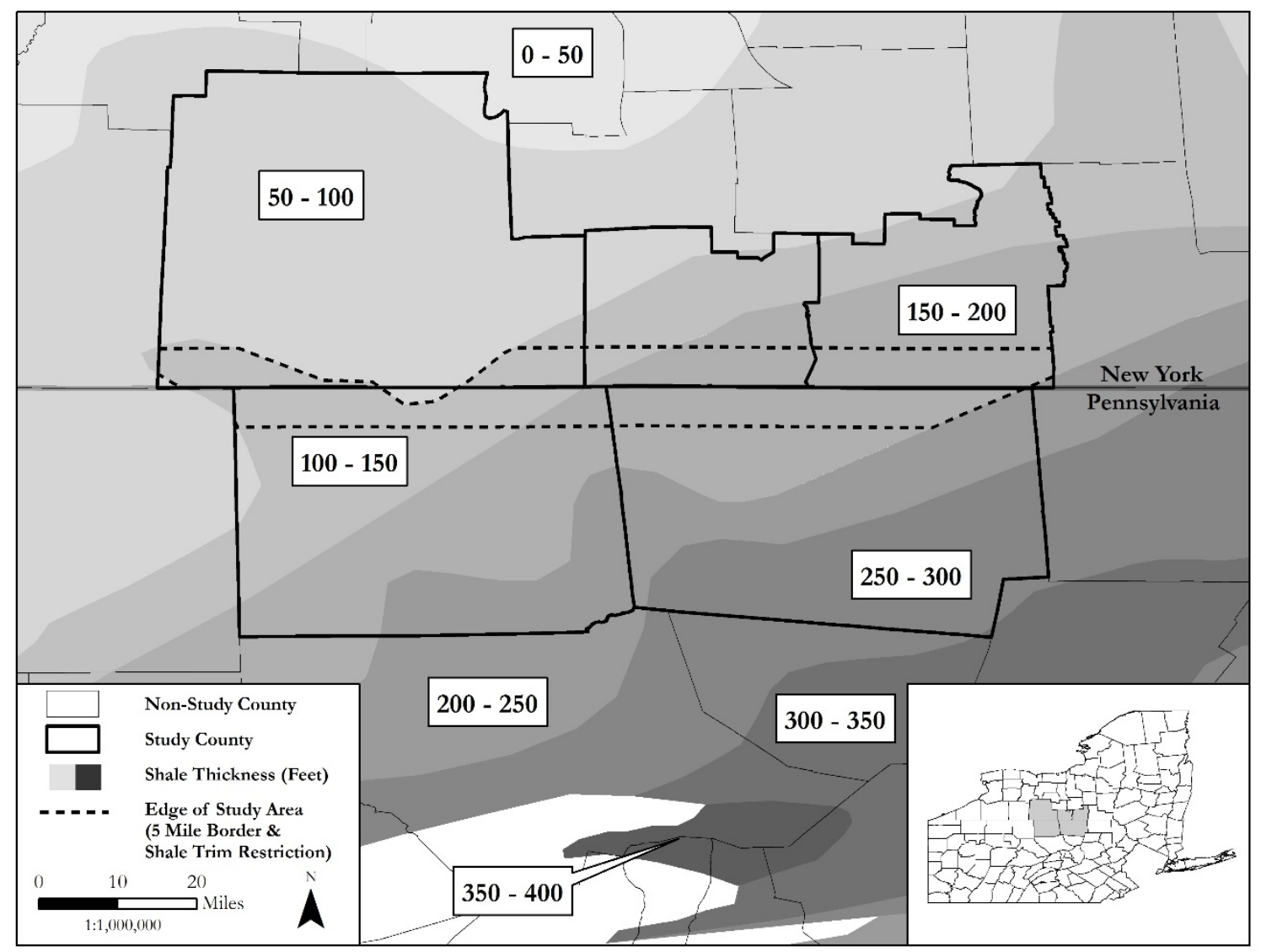

Notes: Geological thickness data is digitized from maps from Pennsylvania State University's Marcellus Center for Outreach and Research (MCOR). 
Figure 4: Pre-moratorium sale price trends

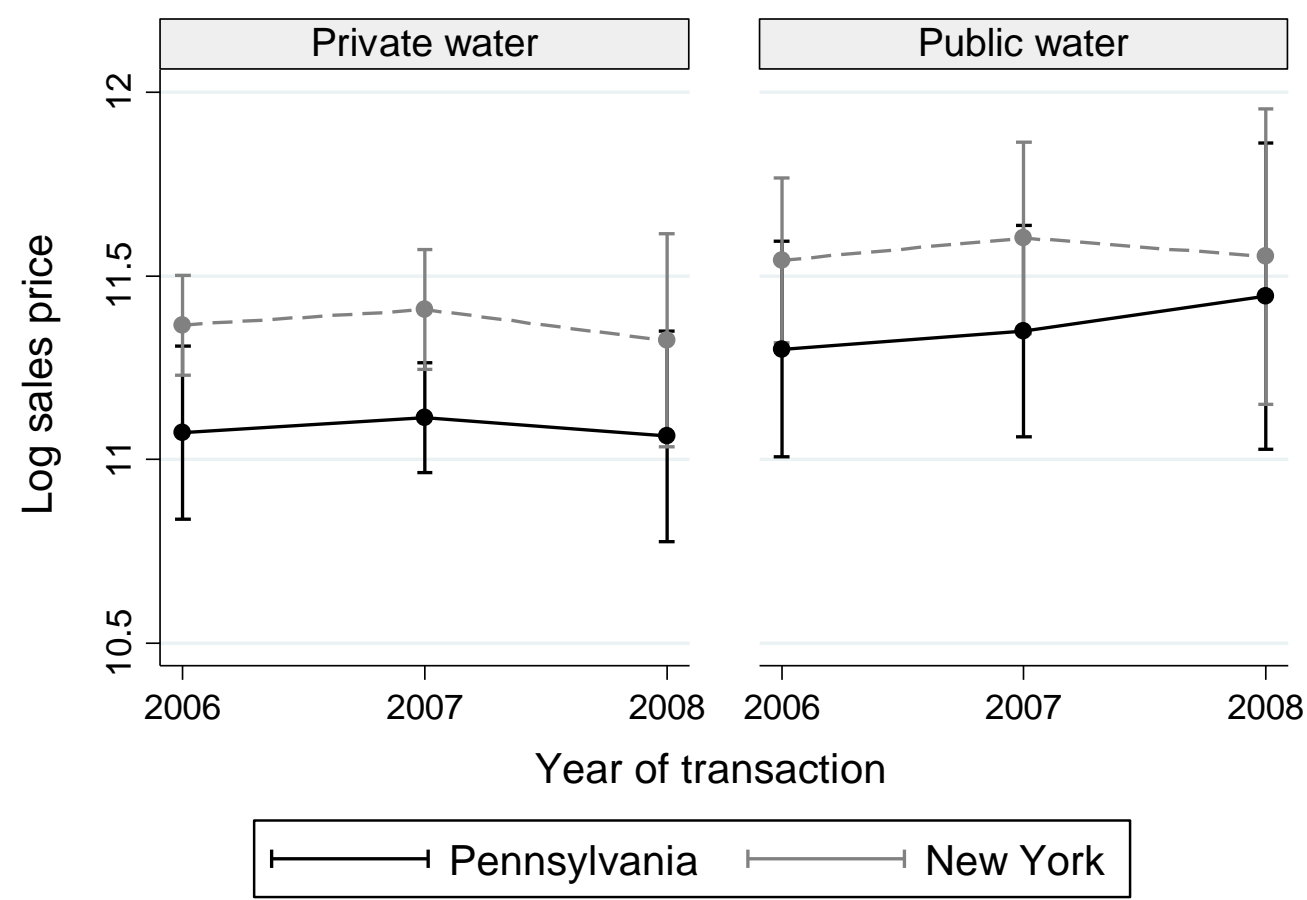

Notes: This sample includes all 1,225 single family residences and mobile homes sold from $\$ 10,000$ to $\$ 1,000,000$ (in 2011 CPI-adjusted dollars) from 2006 to the NY de facto moratorium on SGD (July 23, 2008). Observations are located within 5 miles of the NY-PA border, overlay Marcellus Shale that is $100-200$ feet thick, and are not within two miles of a spud unconventional well. 
Table 1: Summary statistics

\begin{tabular}{|c|c|c|c|}
\hline \multirow[b]{2}{*}{ Variable } & \multirow[b]{2}{*}{ Full Sample } & \multicolumn{2}{|c|}{ Pre-Moratorium Differences: NY - PA } \\
\hline & & Full Sample & $\begin{array}{c}<5 \text { Mile Border \& } \\
\text { Shale Trim } \\
\text { Restrictions }\end{array}$ \\
\hline Price (000s) & 108.09 & 24.18 & 25.67 \\
\hline Lot size (acres) & 3.06 & -0.54 & -0.60 \\
\hline \# of beds & 2.79 & 0.17 & 0.20 \\
\hline \# of baths & 1.41 & 0.07 & -0.12 \\
\hline Finished squared feet (000s) & 1.52 & 0.10 & 0.01 \\
\hline Age at time of sale (years) & 51.20 & 4.34 & 7.40 \\
\hline \# of spud wells: 0 - 3 miles & 2.33 & -0.01 & -0.004 \\
\hline Shale thickness (feet) & 190.07 & $-63.54 *$ & $8.10^{*}$ \\
\hline$\%$ of mobile homes & 0.08 & -0.05 & -0.08 \\
\hline Observations & 4,976 & 2,349 & 449 \\
\hline \multicolumn{4}{|c|}{$\begin{array}{l}\text { Notes: Observations are single family residences and mobile homes located outside of } \\
\text { public water supply areas. Housing prices are CPI-adjusted to } 2011 \text { levels. The } 5 \text { mile } \\
\text { border restrictions includes only those observations that are located within } 5 \text { miles of the } \\
\text { NY-PA state border. The shale trim restriction includes only those observations that overlay } \\
\text { shale that is } 100-200 \text { feet thick. * if the differences in means divided by their combined } \\
\text { standard deviation is greater than } 0.25\end{array}$} \\
\hline
\end{tabular}


Table 2: Double difference estimates of the impact of the NY shale gas development moratorium on housing prices

\begin{tabular}{|c|c|c|c|c|c|}
\hline & (1) & (2) & (3) & (4) & (5) \\
\hline & \multirow{2}{*}{ Full Sample } & \multicolumn{2}{|c|}{$\begin{array}{l}15 \text { Mile Border } \\
\text { Restriction }\end{array}$} & \multicolumn{2}{|c|}{$\begin{array}{l}5 \text { Mile Border } \\
\text { Restriction }\end{array}$} \\
\hline & & Full & Shale Trim & Full & Shale Trim \\
\hline NY * PostMoratorium & $\begin{array}{c}-0.101^{* * *} \\
(0.036)\end{array}$ & $\begin{array}{c}-0.130 * * * \\
(0.039)\end{array}$ & $\begin{array}{c}-0.151^{* * *} \\
(0.045)\end{array}$ & $\begin{array}{c}-0.209 * * * \\
(0.074)\end{array}$ & $\begin{array}{c}-0.231 * * * \\
(0.077)\end{array}$ \\
\hline Property Characteristics & $\mathrm{Y}$ & $\mathrm{Y}$ & $\mathrm{Y}$ & $\mathrm{Y}$ & $\mathrm{Y}$ \\
\hline Year Fixed Effects & Y & Y & $\mathrm{Y}$ & $\mathrm{Y}$ & $\mathrm{Y}$ \\
\hline Township Fixed Effects & Y & Y & Y & $\mathrm{Y}$ & Y \\
\hline Observations & 4,976 & 2,829 & 2,260 & 1,072 & 1,018 \\
\hline R-squared & 0.385 & 0.402 & 0.395 & 0.354 & 0.354 \\
\hline
\end{tabular}

Note: Observations represent single family residence and mobile home property transactions from 2006 to 2011. All observations are located outside of public water supply areas and, thus, rely on private well water. The dependent variable is the natural log of sale price, CPI-adjusted to 2011 values. Property variables include number of beds and bathrooms, a quadratic in square feet of living area, a quadratic in property acreage, a cubic in property age, an indicator variable for mobile home, and an indicator variable for whether some property characteristics were imputed. Standard errors are shown in parentheses and are estimated using township-level cluster-robust inference. *, **, and *** indicate significance at the $10 \%, 5 \%$, and $1 \%$ levels, respectively. 
Table 3: Robustness checks for the 5 mile border restriction and shale thickness model

\begin{tabular}{lcccccc}
\hline & $(1)$ & $(2)$ & $(3)$ & $(4)$ & $(5)$ & $(6)$ \\
\cline { 2 - 7 } & $\begin{array}{c}\text { Exclude } \\
2008\end{array}$ & $\begin{array}{c}\text { Include } \\
2012\end{array}$ & $\begin{array}{c}\text { Thickness } \\
\text { Trim }\end{array}$ & $\begin{array}{c}\text { Thickness } \\
\text { \& Depth } \\
\text { Restrictions }\end{array}$ & $\begin{array}{c}\text { 1 Mile } \\
\text { Border } \\
\text { Cut }\end{array}$ & $\begin{array}{c}\text { Triple } \\
\text { Difference } \\
\text { Approach }\end{array}$ \\
\hline NY* PostMoratorium & $\begin{array}{c}-0.244^{* * *} \\
\text { (0.084) }\end{array}$ & $\begin{array}{c}-0.255^{* * *} \\
(0.078)\end{array}$ & $\begin{array}{c}-0.260^{* *} \\
(0.088)\end{array}$ & $\begin{array}{c}-0.240^{* *} \\
(0.088)\end{array}$ & $\begin{array}{c}-0.231^{* * *} \\
(0.063)\end{array}$ & $\begin{array}{c}-0.050 \\
(0.061)\end{array}$ \\
NY* PostMoratorium & & & & & & $-0.179^{*}$ \\
* Private & & & & & & $(0.100)$ \\
& & & & & & Y \\
\hline Property Characteristics & $\mathrm{Y}$ & $\mathrm{Y}$ & $\mathrm{Y}$ & $\mathrm{Y}$ & $\mathrm{Y}$ & $\mathrm{Y}$ \\
Year Fixed Effects & $\mathrm{Y}$ & $\mathrm{Y}$ & $\mathrm{Y}$ & $\mathrm{Y}$ & $\mathrm{Y}$ & $\mathrm{Y}$ \\
Township Fixed Effects & $\mathrm{Y}$ & $\mathrm{Y}$ & $\mathrm{Y}$ & $\mathrm{Y}$ & $\mathrm{Y}$ & $\mathrm{Y}$ \\
\hline $\begin{array}{l}\text { Observations } \\
\text { R-squared }\end{array}$ & 856 & 1,193 & 826 & 817 & 805 & 2,353 \\
\hline
\end{tabular}

Note: Unless otherwise noted, observations represent single family residence and mobile home property transactions from 2006 to 2011. All observations are located outside of public water supply areas and, thus, rely on private well water. All observations are located within 5 miles of the border and overlay shale from 100 to 200 feet thick. The dependent variable is the natural log of sale price, CPIadjusted to 2011 values. Property variables include number of beds and bathrooms, square footage of finished living area and its squared term, a quadratic in property acreage, and a cubic in property age. Model 1 excludes observations from 2008 for a cleaner break in expectations. Model 2 tests for the robustness of the results with an additional year's worth of sales data from 2012. Model 3 drops all observations in the shale thickness band from 100 - 150 feet, thus only leaving those in the 150 - 200 feet thickness band. In Model 4, we add shale depth trim to our main model (4,000 - 5,000 feet of shale depth) to better control for potential geological differences between the two states. Model 5 drops all properties that are located within a mile of the state border. Model 6 applies a triple difference approach, using properties in both private and public areas. Private is a variable that indicates whether a property is located in a private water supply area. Standard errors are shown in parentheses and are estimated using township-level cluster-robust inference. ${ }^{*}, * *$, and $* * *$ indicate significance at the $10 \%, 5 \%$, and $1 \%$ levels, respectively. 
Table 4: Heterogeneous impacts of the moratorium by acreage and for resolution towns

\begin{tabular}{|c|c|c|}
\hline & $(1)$ & $(2)$ \\
\hline & Acreage Interaction & $\begin{array}{l}\text { Local Resolution } \\
\text { Interaction }\end{array}$ \\
\hline NY $*$ PostMoratorium & $\begin{array}{c}-0.120 * * \\
(0.055)\end{array}$ & $\begin{array}{c}-0.128 * * * \\
(0.046)\end{array}$ \\
\hline NY * PostMoratorium $* \ln ($ Acreage $)$ & $\begin{array}{l}-0.031 \\
(0.040)\end{array}$ & \\
\hline $\begin{array}{l}\text { NY * PostMoratorium * } \\
\text { ResolutionTown }\end{array}$ & & $\begin{array}{l}-0.098 \\
(0.064)\end{array}$ \\
\hline Property Characteristics & $\mathrm{Y}$ & $\mathrm{Y}$ \\
\hline Year Fixed Effects & $\mathrm{Y}$ & $\mathrm{Y}$ \\
\hline Township Fixed Effects & $\mathrm{Y}$ & $\mathrm{Y}$ \\
\hline Observations & 2,260 & 2,260 \\
\hline R-squared & 0.400 & 0.395 \\
\hline $\begin{array}{l}\text { Note: Observations represent single fa } \\
\text { from } 2006 \text { to } 2011 \text {. All observations a } \\
\text { rely on private well water. All observa } \\
\text { shale from } 100 \text { to } 200 \text { feet thick. The c } \\
\text { adjusted to } 2011 \text { values. Property vari } \\
\text { footage of finished living area and its } \\
\text { in property age. The first model intera } \\
\text { quadratic in property acreage with the } \\
\text { DD with a binary variable that indicat } \\
\text { a local resolution in support of shale g } \\
\text { parentheses and are estimated using to } \\
\text { indicate significance at the } 10 \%, 5 \% \text {, }\end{array}$ & $\begin{array}{l}\text { residence and mobile } \\
\text { cated outside of public } \\
\text { are located within } 15 \\
\text { dent variable is the } n \\
\text { include number of be } \\
\text { red term, a quadratic i } \\
\text { e DD with the natura } \\
\text { ral log of acreage. Th } \\
\text { hether an observation } \\
\text { velopment in 2012. S } \\
\text { hip-level cluster-robus } \\
\% \text { levels, respectively }\end{array}$ & $\begin{array}{l}\text { operty transactions } \\
\text { pply areas and, thus, } \\
\text { the border and overlay } \\
\text { of sale price, CPI- } \\
\text { throoms, square } \\
\text { y acreage, and a cubic } \\
\text { reage and replaces the } \\
\text { model interactions the } \\
\text { ed in a town that passed } \\
\text { rrors are shown in } \\
\text { e. } * \text {, **, and } * * *\end{array}$ \\
\hline
\end{tabular}


Table 5: Impact of unconventional well density on residential property prices in Pennsylvania

\begin{tabular}{|c|c|c|c|c|c|c|}
\hline \multirow[b]{4}{*}{ Variables } & \multicolumn{6}{|c|}{ Model Specification - Spatial-Temporal Buffers } \\
\hline & (1) & (2) & (3) & (4) & (5) & (6) \\
\hline & \multicolumn{3}{|c|}{ One Mile Buffer } & \multicolumn{3}{|c|}{ Two Mile Buffer } \\
\hline & $\begin{array}{c}\text { Six } \\
\text { Months }\end{array}$ & $\begin{array}{l}\text { Twelve } \\
\text { Months }\end{array}$ & $\begin{array}{l}\text { All Pre- } \\
\text { Sale }\end{array}$ & $\begin{array}{c}\text { Six } \\
\text { Months }\end{array}$ & $\begin{array}{l}\text { Twelve } \\
\text { Months }\end{array}$ & $\begin{array}{c}\text { All Pre- } \\
\text { Sale }\end{array}$ \\
\hline \# of Spud Wells & $\begin{array}{l}-0.020 \\
(0.029)\end{array}$ & $\begin{array}{l}-0.013 \\
(0.024)\end{array}$ & $\begin{array}{l}-0.015 \\
(0.019)\end{array}$ & $\begin{array}{c}0.002 \\
(0.011)\end{array}$ & $\begin{array}{c}0.009 \\
(0.007)\end{array}$ & $\begin{array}{c}0.002 \\
(0.006)\end{array}$ \\
\hline $\begin{array}{l}\text { \# of Spud Wells * } \\
\text { Private }\end{array}$ & $\begin{array}{c}0.036 \\
(0.034)\end{array}$ & $\begin{array}{c}0.027 \\
(0.027)\end{array}$ & $\begin{array}{c}0.020 \\
(0.019)\end{array}$ & $\begin{array}{c}0.009 \\
(0.011)\end{array}$ & $\begin{array}{l}0.0004 \\
(0.007)\end{array}$ & $\begin{array}{l}-0.001 \\
(0.006)\end{array}$ \\
\hline Property Characteristics & $\mathrm{Y}$ & $\mathrm{Y}$ & $\mathrm{Y}$ & $\mathrm{Y}$ & $\mathrm{Y}$ & $\mathrm{Y}$ \\
\hline Year * Town FE & $\mathrm{Y}$ & $\mathrm{Y}$ & $\mathrm{Y}$ & $\mathrm{Y}$ & Y & $\mathrm{Y}$ \\
\hline Observations & 6,248 & 6,248 & 6,248 & 6,248 & 6,248 & 6,248 \\
\hline R-squared & 0.402 & 0.402 & 0.402 & 0.403 & 0.403 & 0.402 \\
\hline
\end{tabular}

Notes: All observations are single family residences and mobile homes sold in Pennsylvania from 2006 to 2012 for $\$ 10,000$ to $\$ 1,000,000$ (in 2011 CPI-adjusted dollars). Property characteristics include \# of beds, \# of baths, quadratics for acreage and finished square footage, a cubic in age, and binary variables that indicate whether or not the property is in a private water supply area, whether it is a mobile home, and whether it is missing values for beds, baths, finished square footage, or age. Standard errors are shown in parentheses and are estimated using township-level cluster-robust inference. ${ }^{*}, * *$, and $* * *$ indicate significance at the $10 \%, 5 \%$, and $1 \%$ levels, respectively. 